\title{
Homeobox Protein EMX2
}

National Cancer Institute

\section{Source}

National Cancer Institute. Homeobox Protein EMX2. NCI Thesaurus. Code C132086.

Homeobox protein EMX2 (252 aa, $28 \mathrm{kDa}$ ) is encoded by the human EMX2 gene. This protein is involved in the development of the nervous system and the urogenital system. 